\title{
STUDI TENTANG MOTIVASI DAN KARAKTERISTIK PRIBADI KARYAWAN SARI SEHAT HERBAL MEDICINE INDUSTRY di MAGELANG
}

\author{
Yan Kurnia Putri \\ Fakultas Ekonomi Universitas Sarjanawiyata Tamansiswa Yogyakarta \\ puputfadilla@gmail.com
}

\begin{abstract}
Abstrak
This study aims to examine and analyze the influence of personal characteristics on employee motivation Sari Sehat Herbal Medicine Industry and to determine whether the employee motivation Sari Sehat Herbal Medicine Industry in Magelang . Data collected through questionnaires and conducted on 89 employees Sari Sehat Herbal Medicine Industry Magelang. Analysis of the data in this study using SPSS version 17. In this study used a sample of the entire population and data testing techniques used in this study include test validity, reliability tests with Cronbach alpha. Spearman correlation analysis to examine the relationship between personal characteristics such as age, education, length of employment, marital status of the motivation, by comparing the value Sig.phitung with $\alpha$ value (0.05). As for analyzing gender relations to motivation chi square analysis was used to compare the value of Sig $\cdot \chi^{\wedge} 2$ hitung the value of $\alpha(0.05)$. The analysis showed that the level of personal characteristics ( 0.003 ), length of employment ( 0 ) and marital status ( 0.006$)$ effect on employee performance. Age (0.524) and gender (0.217) had no effect on motivation. And the biggest motivation for employees Sari Sehat Herbal Medicine Industry is salary $(79 \%)$.

This research
\end{abstract}

\section{Pendahuluan}

Setiap perusahaan berusaha untuk mencapai tujuan yang telah ditetapkan oleh manajemen puncak. Tujuan perusahaan mencakup pertumbuhan, laba, produktivitas, kesejahteraan karyawan dan sebagainya. Peranan sumber daya manusia sangatlah penting dalam suatu perusahaan. Sumber daya manusia dalam perusahaan berupa kumpulan dari pribadi - pribadi yang dalam suatu organisasi untuk mencapai tujuan bersama.

Dalam rangka untuk mempertahankan aset perusahaan agar dapat tepat daya dan tepat guna, maka perusahaan perlu memberikan stimulasi bagi karyawan untuk dapat bekerja secara optimal. Dalam hal ini, perusahaan perlu mengetahui motivasi karyawan untuk dapat memberikan stimulan yang tepat. Orang dengan karakteristik pribadi yang berbeda memiliki perbedaan kebutuhan dan keinginan serta menunjukkan variasi yang beragam untuk memenuhi kebutuhannya. Yang berarti terdapat perbedaan antara motivasi orang yang satu dengan orang yang lain. Beberapa faktor karakteristik pribadi yang dapat mempengaruhi motivasi karyawan antara lain, gender, usia, pendidikan, status pernikahan, masa kerja.

Sari Sehat adalah perusahaan yang bergerak dalam bidang produksi dan distribusi obat-obatan herbal. Perusahaan yang telah berdiri sejak tahun 1980 ini memiliki karyawan dengan banyak latar belakang yang berbeda, baik dari segi usia, pendidikan, jenis kelamin maupun status pernikahan dll.

\section{Tinjauan Teori}

Keith Davis (1990) perilaku keorganisasian merupakan telaah dan penerapan pengetahuan tentang bagaimana orang-orang bertindak dalam organisasi. Perilaku organisasi adalah sarana manusia 
bagi keuntungan manusia yang dapat diterapkan secara luas dalam perilaku orangorang di semua jenis organisasi. (Husein, $1997: 23$ )

Salah satu pokok bahasan dalam perilaku organisasi adalah motivasi, karena motivasi merupakan salah satu faktor yang mendorong individu untuk menentukan sikap dan pada akhirnya berujung pada perilaku organisasi secara keseluruhan.

Perilaku umumnya dapat diperkirakan jika kita tahu bagaimana orang tersebut menyikapi situasi dan apa yang penting baginya. Meski perilaku seseorang tampak tidak rasional bagi orang lain, terdapat alasan untuk meyakini bahwa perilaku tersebut biasanya dimaksudkan agar rasional dan dianggap rasional. Tentu saja terdapat perbedaan antara orang yang satu dengan yang lain, tergantung dengan beberapa faktor, termasuk salah satunya adalah karakteristik pribadi.

Motivasi berasal dari bahasa latin "movore" yang berarti menimbulkan pergerakan, dorongan atau daya penggerak. Yang berarti bahwa motivasi merupakan daya penggerak untuk orang agar dapat melakukan hal atau mencapai tujuan yang telah ditentukan sebelumnya.

Teori motivasi oleh A. H Maslow (Newstrom (1985:68) :

1. Kebutuhan fisik yang dasar seperti rasa lapar, haus, pakaian dan tempat tinggal.

2. Rasa aman dan jaminan

3. Kebutuhan memiliki dan kebutuhan sosial

4. Penghargaan dan status

5. Perwujudan diri dan pemenuhannya yaitu dorongan untuk menjadi seseorang atau sesuatu sesuai ambisinya.

Semua kebutuhan tingkat pertama merupakan kebutuhan untuk kelangsungan hidup. Dalam situasi kerja kebutuhan ini hampir tidak dominan karena telah cukup terpenuhi. Setelah kebutuhan pada tingkat pertama terpenuhi, maka timbul keinginan untuk memenuhi kebutuhan tingkat selanjutmya.
Teori Motivasi Douglas Mc. Gregor (teori $\mathrm{X} \& \mathrm{Y}$ ) dalam teori ini motivasi dibagi menjadi 2 pandangan yang satu negatif ditandai dengan teori $\mathrm{X}$ dan yang satu positif ditandai dengan teori $\mathrm{Y}$. Dalam teori $\mathrm{X}$ “ Diasumsikan bahwa karyawan tidak menyukai kerja, malas, tidak menyukai tanggung jawab dan harus dipaksa agar berprestasi." Sedangkan dalam teori Y "Diasumsikan bahwa karyawan menyukai kerja, kreatif, berusaha bertanggung jawab dan dapat menjalankan pengarahan diri". Untuk karyawan yang termasuk dalam teori $\mathrm{X}$, maka diasumsikan bahwa kebutuhan tingkat rendah lah yang memotivasi individu. Dan berlaku sebaliknya, untuk karyawan yang termasuk dalam teori y , maka diasumsikan bahwa kebutuhan tingkat tinggi lah yang memotivasi individu (Robbins,2006:216).

Gomes (1995:180-181) menyebutkan faktor - faktor motivasi kerja antara lain needs, goal, attitudes, abilities, pay, job security, co. workers, supervision, praise, job itself. Dimana faktor - faktor tersebut diatas dibagi dalam dua bagian, untuk nomor 1-4 merupakan faktor individu, sedangkan nomor 5-10 merupakan faktor yang bersifat organisasional.

Ketika individu memasuki suatu organisasi, mereka dapat dikatakan sebagai mobil bekas. Setiap individu berbeda, beberapa diantaranya "memiliki jarak tempuh yang pendek" mereka dirawat dengan baik dan hanya sedikit terpengaruh elemen realitas. Sedangkan lainnya “ digunakan secara maksimal" setelah dikendarai melalui medan berat. Metafora ini menunjukkan bahwa individu memasuki organisasi dengan karakteristik utuh tertentu yang akan mempengaruhi perilaku mereka di tempat kerja. Karakteristik yang paling jelas adalah karakteristik pribadi, atau karakteristik yang berkaitan dengan biografi seperti usia, gender, status pernikahan, masa kerja, kerangka emosional bawaan, nilai dan sikap, dan level kemampuan dasar. (Robbins \& Judge, 2007:42-43).

Karakteristik pribadi yang dapat diperoleh dan merupakan data yang obyektif 
adalah karakter biografis seperti usia, gender, status pernikahan, masa kerja (Robbins, 2006:47)

Walaupun sebagian besar teori motivasi tidak menyebutkan tentang karakteristik pribadi, seperti usia, gender, tingkat pendidikan, pengalaman kerja, status pernikahan dsb, akan tetapi dipercaya bahwa faktor-faktor tersebut mempengaruhi motivasi karyawan.

Robbins (2006:49) bagi golongan profesional kepuasan kerja cenderung meningkat di usia tua, akan tetapi pada golongan non profesional, kepuasan kerja cenderung menurun pada usia tua. Itu membuktikan bahwa latar belakang motivasi yang menimbulkan kepuasan kerja pun cenderung berbeda.

Wanita lebih cenderung memiliki tingkat absensi yang tinggi, ini disebakan karena pola mengasuh mereka. Akan tetapi, ketika masyarakat menekankan perbedaan kelamin dan memperlakukan mereka secara berbeda, ada beberapa perbedaan dalam bidang tertentu seperti agresivitas, motivasi dan perilaku sosial. (Gibson dkk, 1996:130131).

Merujuk pada penelitian sebelumnya dalam jurnal Fang Yang, gender yang dimaksudkan dalam penelitian ini adalah jenis kelamin, yaitu laki - laki atau perempuan.

(Eskildsen dkk, 2004) menyebutkan bahwa karyawan dengan pendidikan yang tinggi cenderung kurang puas dengan pekerjaannya dibanding dengan karyawan yang memiliki tingkat pendidikan rendah.

Masa kerja bila dinyatakan sebagai pengalaman kerja, tampaknya menjadi sebuah dasar perkiraan yang baik untuk mengukur produktivitas karyawan. Bukti menunjukkan bahwa masa kerja berpengaruh positif terhadap motivasi dan kepuasan kerja (Robbins ,2006:51).

Pernikahan memaksakan tanggung jawab yang meningkat yang dapat membuat suatu pekerjaan standard menjadi lebih berharga dan penting. Disini menunjukkan adanya perubahan motivasi antara sebelum dan sesudah menikah. (Robbins,2006:51)

\section{Rumusan Masalah}

Penelitian ini dilakukan untuk menjawab dua pertanyaan yaitu :

P1. Apa motivasi kerja karyawan Sari Sehat?

P2.Apakah karakteristik pribadi berpengaruh terhadap motivasi kerja

karyawan Sari Sehat?

\section{Metode Penelitian}

Dalam penelitian ini, penulis akan menggunakan model penelitian kuantitatif, dimana data yang dikumpulkan berasal dari kuesioner yang diberikan kepada responden. Kepada responden akan diberikan dua koesioner. Dimana kuesioner pertama berisi pertanyaan tentang karakteristik pribadi yang meliputi gender, usia, pendidikan, status pernikahan, masa kerja. Sedangkan kuesioner kedua berisi pernyataan tentang faktor motivasi yang akan diberikan opsi dari tidak pernah - selalu, dengan skala 1-5.

Dalam penelitian ini menggunakan dua variabel yang diteliti yaitu motivasi sebagai variabel terikat, dan karakteristik pribadi sebagai variabel bebas. Penelitian dilakukan di Sari Sehat Herbal Medicine Industry, yang diteliti adalah seluruh karyawan Sari Sehat Herbal Medicine Industry yang bekerja di perusahaan pada saat dilakukan penelitian pada September 2013 - Januari 2014. Cara ini dilakukan agar hasil penelitian mewakili setiap karakteristik pribadi. Menurut (Nursallam, 2008:91) “" Semakin banyak sampel maka hasil penelitian mungkin akan lebih representatif. Meskipun keseluruhan populasi terwakilkan, apabila jumlah samplenya kurang memnuhi, maka hasil penelitian dapat kurang atau bahkan tidak dapat mewakili populasi yang sebenarnya"

Data yang dikumpulkan berupa data primer karena dikumpulkan langsung dari responden yang merupakan karyawan Industri Jamu Sari Sehat. 


\section{Uji Validitas}

Kuesioner yang dibuat akan diuji menggunakan uji validitas dan uji reliabilitas. Validitas adalah tingkat keandalan dan kesahihan alat ukur yang digunakan. Kuesioner dikatakan valid berarti menunjukkan alat ukur yang dipergunakan

Tabel 1

Uji Validitas untuk mendapatkan data itu valid atau dapat digunakan untuk mengukur apa yang seharusnya di ukur (Sugiyono, 2007:137). Dengan demikian, instrumen yang valid merupakan instrumen yang benar-benar tepat untuk mengukur apa yang hendak di ukur.

\begin{tabular}{|c|l|c|c|c|}
\hline No & Faktor & $\begin{array}{c}\text { R hitung faktor -faktor } \\
\text { motivasi responden }\end{array}$ & $\begin{array}{c}\text { R } \\
\text { tabel }\end{array}$ & Keterangan \\
\hline 1 & Gaji & 0,475 & 0,206 & Valid \\
\hline 2 & Fasilitas & 0,649 & 0,206 & Valid \\
\hline 3 & Keamanan & 0,450 & 0,206 & Valid \\
\hline 4 & $\begin{array}{l}\text { Lingkungan } \\
\text { kerja }\end{array}$ & 0,317 & 0,206 & Valid \\
\hline 5 & Rekan kerja & 0,294 & 0,206 & Valid \\
\hline 6 & Promosi & 0,625 & 0,206 & Valid \\
\hline 7 & Pelatihan & 0,561 & 0,206 & Valid \\
\hline 8 & Penghargaan & 0,216 & 0,206 & Valid \\
\hline & & & & \\
\hline
\end{tabular}

Sumber : Data primer diolah, 2014

\section{Uji Reliabilitas}

Uji reliabilitas berguna untuk sama akan menghasilkan data yang menetapkan apakah instrumen yang dalam konsisten. Dengan kata lain, reliabilitas hal ini kuesioner dapat digunakan lebih dari satu kali, paling tidak oleh responden yang

instrumen mencirikan tingkat konsistensi.

Tabel 2

\section{Uji Reliabilitas}

\begin{tabular}{|c|c|c|c|c|}
\hline No & Variabel & $\begin{array}{c}\text { Alpha faktor-faktor } \\
\text { motivasi responden }\end{array}$ & R tabel & Keterangan \\
\hline 1 & Motivasi & 0,739 & 0,206 & Reliabel \\
\hline & & & & \\
\hline
\end{tabular}

Sumber : Data primer diolah, 2014

\section{Alat Analisis Data}

Alat analisis yang digunakan dalam penelitian ini adalah uji korelasi Spearman untuk menguji hubungan antara usia, tingkat pendidikan, status pernikahan, masa kerja dengan motivasi kerja karyawan. Dan uji Chi
Square untuk menguji hubungan antara gender dengan motivasi kerja.

\section{Analisis Korelasi Spearman}

Uji korelasi Spearman digunakan untuk memahami suatu fenomena dengan 
menentukan derajat hubungan antara variabel-variabel. Tingkat hubungan tersebut ditunjukkan oleh nilai koefisien korelasi yang berfungsi sebagai alat untuk membandingkan variabilitas hasil pengukuran terhadap variabel-variabel tersebut. Pengetahuan tentang tingkat hubungan tersebut diharapkan dapat menambah pemahaman tentang faktor-faktor dalam karakteristik yang kompleks dari suatu fenomena

Pengujian dilakukan dengan membandingkan antara nilai phitung dengan nilai $\rho$ tabel dengan nilai siginifikasi $\alpha=0,05$. Jika hasil perhitungan menunjukkan :

1. Jika phitung $\leq$ ptabel maka Ho diterima

2. Jika phitung $>$ ptabel maka Ho ditolak

Atau

3. Jika sig phitung $\leq(\alpha=0,05)$ maka Ho diterima

4. Jika sig phitung $>(\alpha=0,05)$ tabel maka Ho ditolak

Apabila nilai sig phitung berniliai positif maka terdapat hubungan yang berbanding lurus. Dimana apabila $\mathrm{x}$ meningkat maka y juga ikut meningkat dan berlaku sebaliknya. Apabila nilai sig phitung bernilai negatif maka terdapat hubungan yang berbanding terbalik. Dimana apabila $x$ meningkat, maka y akan menurun dan hal tersebut berlaku sebaliknya. Nilai korelasi phitung menunjukkan kekuatan hubungan kedua variabel tersebut. Semakin tinggi nilai phitung (mendekati 1) maka semakin kuat pula hubungan kedua variabel. Berikut rentang kekuatan korelasi phitung. ( 0,000$0,199=$ sangat lemah, 0,200-0,399 = lemah, 0,400-0,599 = sedang, 0,600-0,799 = kuat, $0,800-1,000=$ sangat kuat $)$.

\section{Analisis Chi Kuadrat}

Untuk menguji apakah ada hubungan antara karakteristik pribadi khususnya gender dengan motivasi kerja karyawan, digunakan alat analisis uji kai kuadrat yang dilambangkan dengan " $X^{2}$ " dari huruf
Yunani "Chi " yang dilafalkan "Kai" digunakan untuk menguji dua kelompok data baik variabel independen maupun dependennya berbentuk kategorik dan dapat juga dikatakan sebagai uji proporsi untuk dua peristiwa atau lebih sehingga datanya bersifat diskrit.

Dasar uji kai kuadrat sendiri adalah membandingkan perbedaan frekuensi hasil observasi (O) dengan frekuensi yang diharapkan (E) (Usman \& Purnomo : 2000). Perbedaan tersebut meyakinkan jika nilai dari kai kuadrat sama atau lebih besar dari suatu nilai yang ditetapkan dalam signifikasi tertentu.

Adapun syarat - syarat yang harus dipenuhi dalam uji kai kuadrat adalah jumlah sampel harus cukup besar, pengamatan harus bersifat independen, dan hanya dapat digunakan pada data deskrit atau data kontinu yang telah dikelompokkan menjadi kategori.

Pengujian dilakukan dengan membandingkan antara $X^{2}$ hitung dengan

$X^{2}$ tabel pada $\alpha=0,05$. Jika hasil

perhitungan menunjukkan :

1. Jika $X^{2}$ hitung $\leq X^{2}$ tabel maka Ho diterima

2. Jika $X^{2}$ hitung $>X^{2}$ tabel maka Ho ditolak

Atau

3. Jika $\operatorname{sig} X^{2}$ hitung $\leq(\alpha=0,05)$ maka Ho diterima

4. Jika $\operatorname{sig} X^{2}$ hitung $>(\alpha=0,05)$ tabel maka Ho ditolak

\section{Hasil dan Pembahasan}

Dari kuesioner yang dibagikan kepada responden saat penelitian, maka dapat disimpulkan karyawan Sari Sehat terdiri dari 34 orang laki-laki dan 55 orang perempuan. Responden dengan rentang usia $20-30$ th sebanyak $15 \%, 31-40$ th sebanyak $53 \%, 41-50$ th sebanyak $28 \%, 51-60$ th sebanyak 4\%. Responden yang berpendidikan SD sebanyak 8\%, berpendidikan SMP sebanyak 31\%, SMA 
sebanyak $42 \%$ dan S1 sebanyak 19\%. Resonden dengan masa kerja 1-5 th sebanyak $19 \%$, 6-10 th sebanyak $20 \%, 11-15$ th sebanyak $43 \%,>15$ th sebanyak $18 \%$. Responden yang sudah menikah sebanyak $90 \%$, belum menikah sebanyak 9\%, janda sebanyak $1 \%$.

Dari kuesioner yang dibagikan, didapatkan hasil sebanyak $79 \%$ responden setuju bahwa gaji merupakan hal yang memotivasi karyawan untuk bekerja. Sebanyak 56\% responden menjawab setuju bahwa jaminan kesehatan merupakan salah satu faktor motivasi karyawan untuk memilih bekerja di perusahaan. Sebanyak 62\% menjawab setuju bahwa status kerja sebagai karyawan teteap merupakan salah satu faktor motivasi. Sebanyak $61 \%$ menjawab setuju bahwa lingkungan kerja yang aman merupakan motivasi untuk bekerja. Sebanyak $69 \%$ responden menjawab setuju bahwa kekeluargaan yg tinggi membuat motivasi responden untuk bekerja.Sedangkan untuk faktor motivasi berupa promosi kerja, sebanyak 51\% menjawab netral. Ini dapat diartikan, ada atau tidak adanya promosi jabatan , tidak menjadi pengaruh signifikan bagi motivasi kerja. Sama dengan faktor promosi jabatan, faktor pelatihan kerja juga tidak menjadi motivasi bagi sebagian besar karyawan, ini dapat dilihat dari hasil yang diperoleh adalah 38\% menjawab netral. Sedangkan untuk faktor penghargaan non materiil hasil yang diperoleh adalah 44\% menjawab setuju, itu berarti bagi karyawan penghargaan dari perusahaan yang tidak bersifat materiil juga dapat menjadi salah satu faktor motivasi kerja.

Analisis korelasi spearman digunakan dalam penelitian ini, untuk menganalisis pengaruh karakteristik pribadi (X) seperti usia, pendidikan, masa kerja, status pernikahan terhadap motivasi (Y). Secara statistik hasil analisis korelasi dapat dilihat pada tabel berikut ini :

Tabel 3

Hasil Analisi Korelasi X (Usia, Pendidikan, Masa Kerja, Status Pernikahan) terhadad Y (Motivasi)

\begin{tabular}{|c|c|c|c|c|c|c|c|}
\hline \multicolumn{8}{|c|}{ Correlations } \\
\hline & & & $\begin{array}{c}\text { Motiva } \\
\text { si }\end{array}$ & Usia & Pendidikan & $\begin{array}{l}\text { Lama } \\
\text { Kerja }\end{array}$ & $\begin{array}{c}\text { Status } \\
\text { Pernikaha } \\
\text { n }\end{array}$ \\
\hline \multirow[t]{7}{*}{$\begin{array}{l}\text { Spearm } \\
\text { an's rho }\end{array}$} & \multirow[t]{3}{*}{$\mathrm{i}^{\text {Motivas }}$} & $\begin{array}{l}\text { Correlati } \\
\text { on } \\
\text { Coefficie } \\
\text { nt }\end{array}$ & $\begin{array}{c}1 \\
.000\end{array}$ & 068 & $.307^{* *}$ & $63^{.3}$ & $.287^{* *}$ \\
\hline & & $\begin{array}{l}\text { Sig. (2- } \\
\text { tailed) }\end{array}$ & & .524 & .003 & .000 & .006 \\
\hline & & $\mathrm{N}$ & 89 & 89 & 89 & 89 & 89 \\
\hline & \multirow[t]{3}{*}{ Usia } & $\begin{array}{l}\text { Correlati } \\
\text { on } \\
\text { Coefficie } \\
\text { nt }\end{array}$ & .068 & 1.000 & $-.290^{* * *}$ & $.472^{* * *}$ & $-.360^{* * *}$ \\
\hline & & $\begin{array}{l}\text { Sig. (2- } \\
\text { tailed) }\end{array}$ & .524 & & .006 & .000 & .001 \\
\hline & & $\mathrm{N}$ & 89 & 89 & 89 & 89 & 89 \\
\hline & $\begin{array}{l}\text { Pendidik } \\
\text { an }\end{array}$ & $\begin{array}{l}\text { Correlati } \\
\text { on } \\
\text { Coefficie }\end{array}$ & $-.307^{* * *}$ & $.290^{* *}$ & 1.000 & $-.388^{* * *}$ & $.285^{* *}$ \\
\hline
\end{tabular}


JURNAL MANAJEMEN VOL. 4 NO. 1 JUNI 2014

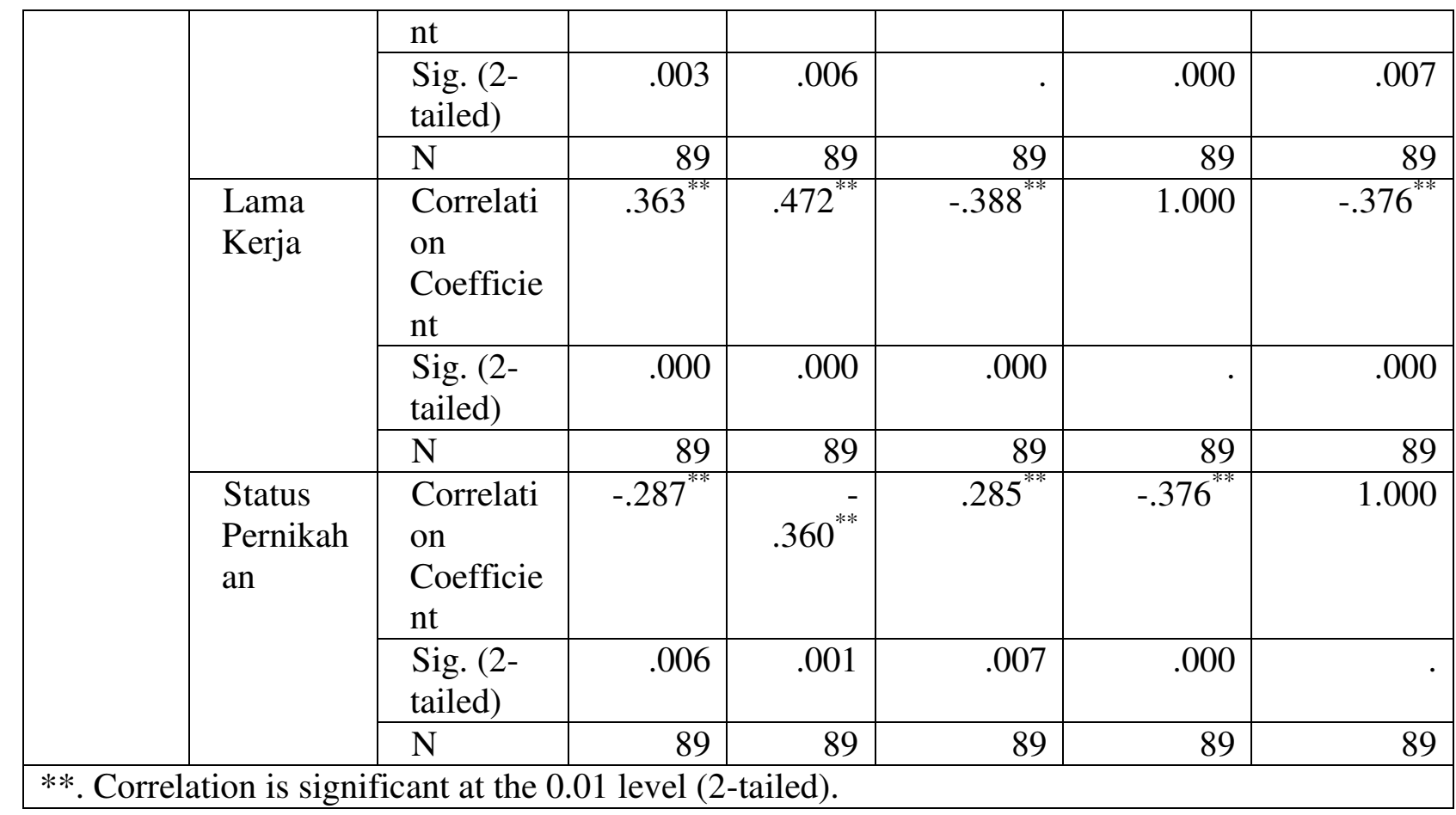

Sumber : Data primer diolah, 2014

Untuk melihat ada tidaknya hubungan antara dua variabel maka dilihat dari nilai Sig.(2-tailed) nya untuk tiap variabel apabila .> 0,05 maka Ho diterima sedangkan apabila $<0,05$ maka Ho ditolak. Analisis kedua, dilihat dari nilai phitung untuk masing-masing karakteristik pribadi berikut ini : usia $=0,068$, pendidikan $=$ 0,307 , lama kerja $=0,363$, status pernikahan $=-0,287$.

Dari data analisis yang didapatkan, maka dapat disimpulkan bahwa motivasi dan usia menunjukkan nilai sig.(2-tailed) $=0,524>$ 0,05 yang berarti Ho diterima atau tidak ada hubungan antara motivasi dengan usia. Hubungan antara motivasi dan usia menghasilkan nilai phitung $=0,068$ yang berarti hubungan antara motivasi dan usia sangat lemah dan bernilai (+) berarti semakin banyak usia-nya maka semakin besar juga faktor motivasinya. Motivasi dan pendidikan menunjukkan nilai sig.(2-tailed) $=0,003<$ 0,05 yang berarti Ho ditolak atau terdapat hubungan antara motivasi dengan pendidikan. Hubungan antara motivasi dan pendidikan menghasilkan nilai phitung = 0,307 yang berarti hubungan antara kedua variabel lemah dan bernilai (-) berarti semakin tinggi tingkat pendidikannya maka semakin kecil motivasinya dan berlaku sebaliknya. Motivasi dan lama kerja menunjukkan nilai sig.(2-tailed) $=0<0,05$ yang berarti Ho ditolak atau terdapat hubungan antara motivasi dan masa kerja. Hubungan antara motivasi dan lama kerja menghasilkan nilai phitung $=0,363$ yang berarti hubungan antara kedua variabel lemah dan bernilai $(+)$ berarti semakin lama masa kerja maka semakin besar pula motivasi. Motivasi dan status pernikahan menunjukkan nilai sig. $(2$-tailed) $=0,006<$ 0,05 yang berarti Ho ditolak atau terdapat hubungan antara motivasi dan status pernikahan. Hubungan antara motivasi dan status pernikahan menghasilkan nilai phitung $=-0,287$ yang berarti hubungan kedua variabel lemah dan bernilai (-) menunjukkan bahwa semakin tinggi status pernikahan maka semakin rendah motivasinya dan juga berlaku sebaliknya.

Analisis Chi Square dilakukan untuk menguji ada tidaknya hubungan antara gender dan motivasi kerja karyawan Sari Sehat Herbal Medicine Industry. Secara statistik hasil uji dapat terlihat pada tabel dibawah ini 
Tabel 10

Analisis Chi Square Gender Terhadap Faktor Motivasi

Chi-Square Tests

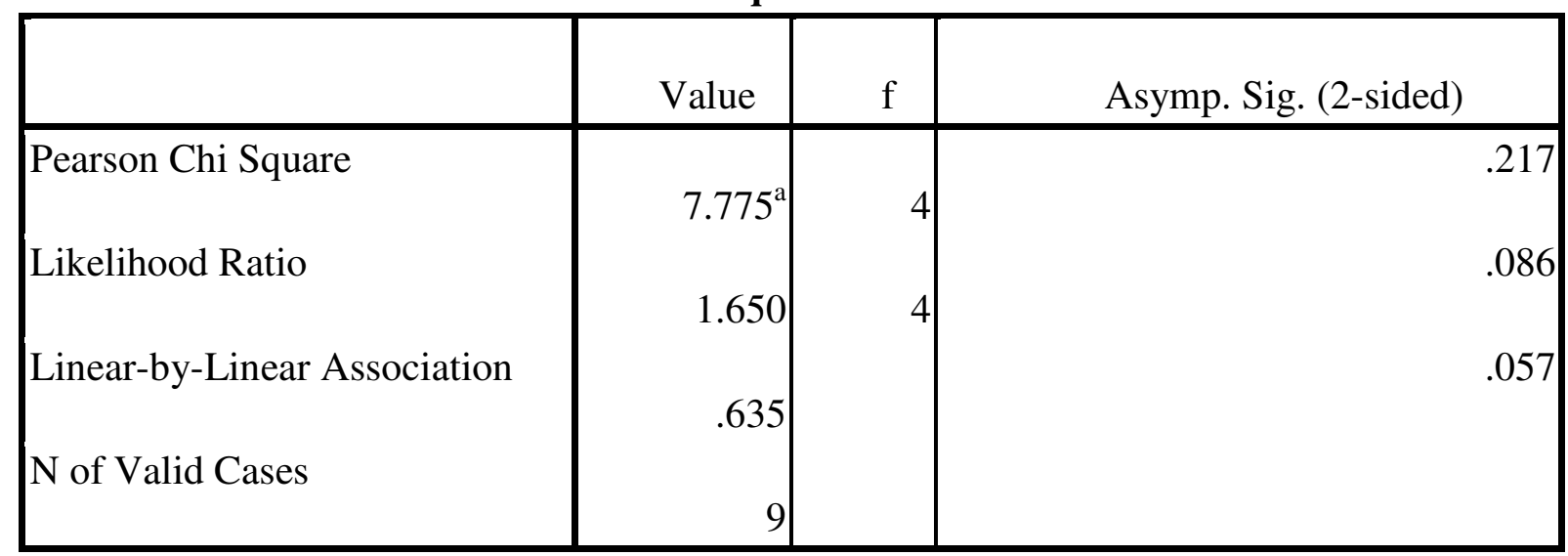

a. 26 cells $(86,7 \%)$ have expected count less than 5 . The minimum expected count is ,38.

Sumber : Data primer Diolah, 2014

Dari tabel tersebut diatas maka dapat diinterpretasikan hasilnya sebagai berikut, nilai Chi-square hitung $=17,775$ sedangkan nilai chi square tabel dengan df $=14$ dan tingkat signifikasi $5 \%$ adalah 23,685, maka chi-square hit $<$ dari chisquare tabel. Maka Ho diterima atau tidak ada hubungan antara gender dengan motivasi kerja. Nilai Sig,(2-sided) $=0,217$ $>0,05$ maka Ho Diterima atau tidak ada hubungan antara gender dan motivasi.

Dari analisis yang telah dilakukan untuk menguji hubungan karakteristik pribadi terhadap motivasi maka dapat disimpulkan beberapa hal. Karakteristik pribadi tidak semuanya berpengaruh terhadap motivasi kerja yang dimiliki oleh karyawan Sari Sehat Herbal Medicine Industry. Dari hasil uji korelasi spearman diperoleh bahwa faktor usia tidak berpengaruh terhadap motivasi. Artinya adalah bahwa semakin muda ataupun semakin tua usia responden tidak berpengaruh terhadap motivasi kerja.

Sedangkan faktor pendidikan, lama kerja dan status pernikahan, berpengaruh terhadap motivasi kerja karyawan. Ini berarti bahwa pendidikan karyawan yang berbeda antara satu karyawan dengan karyawan yang lain, maka dapat berbeda pula motivasi kerjanya, karyawan senior memliki perbedaan motivasi dengan karyawan junior, karyawan menikah memiliki perbedaan motivasi dengan karyawan yang belum menikah.

Sedangkan melalui analisis chisqure diperoleh hasil berupa tidak ada hubungan antara faktor gender dengan motivasi kerja. Hal ini berarti tidak ada perbedaan motivasi antara laki-laki dan wanita secara keseluruhan.

Pengaruh faktor pendidikan, lama kerja dan status pernikahan terhadap motivasi kerja bersifat lemah, hal ini dilihat dari nilai phitung pada uji korelasi yang menghasilkan kisaran angka pada range lemah. Kisaran hasil phitung pendidikan 0,307 , lama kerja 0,363 , status pernikahan 0,287 , ketiga phitung tersebut masuk dalam kisaran lemah yaitu $0,200-0,399$. Ini berarti ada hubungan antara pendidikan, lama kerja dan status pernikahan, akan tetapi hubungannya lemah dan tidak terlalu signifikan.

Hubungan antara faktor pendidikan dan motivasi berbanding terbalik, ini dilihat dari nilai phitung yang bernilai negatif. Dimana apabila pendidikan semakin tinggi maka motivasi kerja semakin rendah. Demikian juga hal tersebut berlaku untuk 
hubungan status pernikahan dengan motivasi.

Hubungan antara lama kerja dan motivasi berbanding lurus, ini dilihat dari nilai phitung yang bernilai positif. Dimana apabila semakin lama karyawan bekerja di perusahaan maka semakin besar pula motivasinya.

Berdasarkan hasil analisis data maka dapat dikatakan faktor motivasi kerja berupa gaji merupakan motivasi utama karyawan untuk bekerja di perusahaan. Hal itu dapat dilihat dari pengumpulan data kuesioner karyawan yang setuju dengan pernyataan tersebut sebanyak $79 \%$.

Sedangkan untuk peringkat kedua sebanyak $69 \%$ responden memilih rekan kerja sebagai faktor yang memotivasi kerja. Rekan kerja yang memiliki rasa kekeluargaan yang tinggi menjadi salah satu hal yang memotivasi karyawan untuk bekerja. Rasa kekeluargaan yang tinggi juga membuat kondisi kerja nyaman sehingga lebih menyenangkan dalam bekerja.

Dan pada peringkat ketiga sebanyak $62 \%$ responden memilih keamanan sebagai faktor yang memotivasi kerja. Keamanan yang diberikan perusahaan berupa status pegawai tetap menjadi salah satu faktor yang memotiasi karyawan untuk bekerja. Hal ini karena karyawan tidak perlu takut pada kemungkinan pemberhentian kerja sewaktuwaktu seperti yang dialami oleh karyawan dengan status kerja kontrak.

\section{Kesimpulan}

Penelitian ini bertujuan untuk meneliti pengaruh karakteristik pribadi terhadap motivasi kerja karyawan Sari Sehat herbal Medicine Industry dan untuk mengetahui apakah motivasi kerja karyawan Sari Sehat Herbal Medicine Industry. Berdasarkan hasil penelitian yang telah dilakukan terhadap 89 responden, maka dapat disampaikan kesimpulan sebagai berikut, setelah melakukan pengujian menggunakan analisis korelasi, maka disimpulkan, terdapat pengaruh pendidikan, lama kerja dan status pernikahan terhadap motivasi kerja. Setelah melakukan pengujian menggunakan analisis korelasi, disimpulkan tidak ada hubungan antara usia dengan faktor motivasi. Setelah melakukan pengujian menggunakan analisis chi square maka disimpulkan, tidak ada pengaruh antara gender dengan faktor motivasi. Motivasi utama karyawan untuk bekerja pada peringkat pertama adalah gaji dengan pilihan responden sebanyak $79 \%$, pada tempat kedua adalah rekan kerja sebanyak 69\%, dan urutan ketiga adalah keamanan sebanyak $62 \%$.

\section{Referensi}

Eskildsen , J.K., Kristensen, K. and Westlund, A.H., "Work Motivation and Job Satisfaction in the nordic Countries", Vol 26 No. 2.

Fang Yang, "Work, motivation and personal characteristics: an in depth study of six organizations on Ningbo", Ningbo Institute of Education, Republic of China.

Gibson, J.L., Ivancevich, J.M., Donnelly, J.H., 1996, “Organisasi”, Edisi Kedelapan, Jilid 1, Binarupa Aksara.

Gomes, F.C, 1995, "Manajemen Sumber Daya Manusia", Andi Penerbit.

Husein, Umar, 1997, "Riset Sumber Daya Manusia Dalam Organisasi", Jakarta : Gramedia Pustaka Utama.

Newstrom, J.W, 1985, "Perilaku Organisasi" ( diterjemahkan oleh Agus Dharma, S.H), Edisi ke 7, Erlangga.

Nursallam, 2008, "Konsep dan Penerapan Metodelogi Penelitian Ilmu Keperawatan" Edisi Ke 2, Salemba Medika.

Robbins, S.P, 2006, "Perilaku Organisasi”, Edisi ke-10, Indeks.

Robbins, S.P. dan Judge, T.A, 2007, "Perilaku Organisasi", Edisi 12, Indeks.

Sugiyono, 2007, "Metode Penelitian Administrasi", Bandung : Alfabeta. 